\title{
Long-Term Effects of Red- and Blue-Light Emitting Diodes on Leaf Anatomy and Photosynthetic Efficiency of Three Ornamental Pot Plants
}

\section{OPEN ACCESS}

Edited by:

Leo Marcelis,

Wageningen University and Research

Centre, Netherlands

Reviewed by:

Andreas Savvides,

Cyprus University of Technology,

Cyprus

Phillip Andrew Davis,

Stockbridge Technology Centre,

United Kingdom

${ }^{*}$ Correspondence:

Marie-Christine Van Labeke mariechristine.vanlabeke@ugent.be

Specialty section:

This article was submitted to Crop Science and Horticulture, a section of the journal

Frontiers in Plant Science

Received: 27 March 2017

Accepted: 16 May 2017

Published: 30 May 2017

Citation:

Zheng L and Van Labeke M-C (2017) Long-Term Effects of Red-and Blue-Light Emitting Diodes on Leaf Anatomy and Photosynthetic Efficiency of Three Ornamental Pot Plants. Front. Plant Sci. 8:917. doi: 10.3389/fpls.2017.00917

\section{Liang Zheng and Marie-Christine Van Labeke* \\ Department of Plant Production, Ghent University, Gent, Belgium}

Light quality critically affects plant development and growth. Development of light-emitting diodes (LEDs) enables the use of narrow band red and/or blue wavelengths as supplementary lighting in ornamental production. Yet, long periods under these wavelengths will affect leaf morphology and physiology. Leaf anatomy, stomatal traits, and stomatal conductance, leaf hydraulic conductance $\left(\mathrm{K}_{\text {leaf }}\right)$, and photosynthetic efficiency were investigated in three ornamental pot plants, namely Cordyline australis (monocot), Ficus benjamina (dicot, evergreen leaves), and Sinningia speciosa (dicot, deciduous leaves) after 8 weeks under LED light. Four light treatments were applied at $100 \mu \mathrm{mol} \mathrm{m} \mathrm{m}^{-2} \mathrm{~s}^{-1}$ and a photoperiod of $16 \mathrm{~h}$ using $100 \%$ red $(\mathrm{R}), 100 \%$ blue (B), $75 \%$ red with $25 \%$ blue (RB), and full spectrum white light $(\mathrm{W})$, respectively. $B$ and $R B$ resulted in a greater maximum quantum yield $\left(F_{v} / F_{m}\right)$ and quantum efficiency $\left(\Phi_{\mathrm{PSII}}\right)$ in all species compared to $\mathrm{R}$ and $\mathrm{W}$ and this correlated with a lower biomass under $\mathrm{R}$. $B$ increased the stomatal conductance compared with $\mathrm{R}$. This increase was linked to an increasing stomatal index and/or stomatal density but the stomatal aperture area was unaffected by the applied light quality. Leaf hydraulic conductance (K $K_{\text {leaf }}$ ) was not significantly affected by the applied light qualities. Blue light increased the leaf thickness of F. benjamina, and a relative higher increase in palisade parenchyma was observed. Also in S. speciosa, increase in palisade parenchyma was found under B and RB, though total leaf thickness was not affected. Palisade parenchyma tissue thickness was correlated to the leaf photosynthetic quantum efficiency $\left(\Phi_{\mathrm{PS} I I}\right)$. In conclusion, the role of blue light addition in the spectrum is essential for the normal anatomical leaf development which also impacts the photosynthetic efficiency in the three studied species.

Keywords: leaf anatomy, leaf hydraulic conductance, chlorophyll fluorescence, stomatal conductance, Ficus benjamina, Sinningia speciosa, Cordyline australis

\section{INTRODUCTION}

Light strongly influences plant growth and development. Light, as an energy source, affects photosynthesis and its related parameters. Light quality is one of the main factors of light signaling and affects numerous processes from seed germination, leaf formation to flower development (Hogewoning et al., 2010; Wang et al., 2010; Johkan et al., 2012; Demotes-Mainard et al., 2016). 
Artificial lighting has been used to extend the photoperiod and to increase the light intensity in horticultural production. Development of light-emitting diodes (LEDs) enables the application of narrow spectrum band red or blue wavelengths in the cultivation of horticultural crops at the exact absorption peaks of chlorophyll (Dutta Gupta and Jatothu, 2013) which in shortterm results in the highest photosynthetic efficiencies per leaf unit area (McCree, 1971). Yet, long periods under monochromatic or dichromatic wavelengths with low natural light fluencies might lead to many morphological and physiological changes in response to the ambient light environment thus affecting plant development (Terashima and Saeki, 1983; Brodersen and Vogelmann, 2010; Demotes-Mainard et al., 2016; Huché-Thélier et al., 2016).

Various traits affecting photosynthesis are influenced by light quality including both red and blue light responses. Leaf anatomy may directly influence light capture by its leaf thickness as well as by the differentiation of palisade and spongy mesophyll. Schuerger et al. (1997) reported that leaf thickness increased when red light was supplemented with blue light. Light absorption will also be dependent on chlorophyll concentration. Wang et al. (2009) reported that blue light enhanced the expression of different enzymes such as $\mathrm{MgCH}$, GluTR, and $\mathrm{FeCH}$ which regulate the synthesis of chlorophyll. Red light is less conducive for the chlorophyll biosynthesis, because of its reduction of the tetrapyrrole precursor 5-aminolevulinic acid (Sood et al., 2005; Fan et al., 2013). Stomatal density and conductance are other traits that will influence the $\mathrm{CO}_{2}$ uptake and thus photosynthesis. Effects of blue light on stomatal opening are well documented (Tallman and Zeiger, 1988; Talbott, 2002). Monochromatic red light has been reported to reduce the photosynthetic efficiency and it leads to photo-damage after a long-term exposure (Trouwborst et al., 2016). In contrast, blue light which is sensed by cryptochrome and phototropin optimizes photosynthesis by improving the efficiency of light capture, reducing photo-damage, and regulating gas exchange between leaves and atmosphere (Takemiya et al., 2005).

Light quality not only affects the gas exchange but also the water transportation within leaves (Sharkey and Raschke, 1981; Lee et al., 2007; Savvides et al., 2012). Leaf hydraulic conductance $\left(\mathrm{K}_{\text {leaf }}\right)$ affects different aspects of plant functioning such as respiration, evaporation, and photosynthetic carbon fixation (Prado and Maurel, 2013). Leaf hydraulic conductance reflects the water flow through the leaf veins, across the mesophyll tissue and to the stomatal aperture. The extra-veinal phase of water flow is influenced by the leaf mesophyll spongy/palisade anatomy and thickness and the stomatal aperture characteristics (Nardini et al., 2003; Sack et al., 2004; Sack and Holbrook, 2006). Despite the great importance of leaf hydraulic conductance in plant water relations, knowledge of the relationships between hydraulic conductance and light quality is limited. Savvides et al. (2012) reported that blue in the light spectrum drives both $\mathrm{K}_{\text {leaf }}$ and $g_{s}$ toward higher values in cucumber. In bur oak, hydraulic conductivity was enhanced in response to blue and green light (Voicu et al., 2008).

In ornamental horticulture, the commercial value depends on the visual quality, which mainly results from architectural traits such as stem elongation, compactness, branching, and flowering. The management of light quality opens the way to improved control of the ornamental value. Control of the light quality by LED lights could also focus on a specific production phase namely the ornamental young plants where LED could be the sole-source light in multilayer production units. However, this phase under monochromatic or dichromatic narrow band LED lights might not only influence the architectural traits but also anatomical traits of leaves developing under this light treatment.

The objective of this study was to evaluate how narrowband R, B, and RB would modulate leaf morphology, mesophyll anatomy and stomatal formation, which could in consequence influence the light absorption and hydraulic conductance of leaves. To assess the impact on photosynthetic performance chlorophyll fluorescence parameters were quantified as well as the biomass. For this study we selected three commonly produced ornamentals with different leaf traits namely Cordyline australis (monocot), Ficus benjamina (dicot, evergreen leaves), and Sinningia speciosa (dicot, deciduous leaves).

\section{MATERIALS AND METHODS}

\section{Plant Material and Growth Conditions}

The experiment was conducted in a growth chamber at Ghent University, Belgium. Three ornamental species were selected: $C$. australis "Red Star" (monocot), F. benjamina "Exotica" (dicot, evergreen leaves), and S. speciosa "Sonata Red" (dicot, deciduous leaves). Young plants were obtained from a commercial plant producer and transplanted into $0.3 \mathrm{~L}$ pots filled with peatbased potting soil (Van Israel nv, Belgium). The plants were acclimated for 1 week in broad spectrum light $\left(100 \mu \mathrm{mol} \mathrm{m}{ }^{-2}\right.$ $\mathrm{s}^{-1}$ ) provided by SON-T high pressure sodium lamps (Philips Inc., Eindhoven, the Netherlands). Then for each species, 12 replicates per treatment were randomly allocated to four spectral light treatments. Air temperature of the growth chamber was set at $22 \pm 2^{\circ} \mathrm{C}$ and plants received a photoperiod of $16 \mathrm{~h}$. Irrigation and fertilization with a water-soluble fertilizer (N:P:K $=4: 1: 2, \mathrm{EC}$ $1.5 \mathrm{ds} \mathrm{m}^{-1}, \mathrm{pH}=6.5$ ) was applied once every 2 days.

\section{Light Treatment}

Light intensity at the canopy level was set at $100 \mu \mathrm{mol} \mathrm{m} \mathrm{m}^{-2} \mathrm{~s}^{-1}$ by adjusting the distance of the light source and a photoperiod of $16 \mathrm{~h}$ per day was given. Light treatment sections were separated with curtains, four treatments were applied using different light qualities equipped with LED lighting, which were B (100\% blue, peak at $460 \mathrm{~nm}), \mathrm{R}(100 \% \mathrm{red}, 660 \mathrm{~nm})$, and $\mathrm{W}$ [white, $7 \%$ blue $(400-500 \mathrm{~nm}), 16 \%$ green $(500-600 \mathrm{~nm}), 75 \%$ red $(600-700 \mathrm{~nm})$, and $2 \%$ far red (700-800 nm)] (Philips Inc., Eindhoven, The Netherlands) as well as RB (75\% R and 25\% B, peak at 460 and $660 \mathrm{~nm}$ ) by a CID-800 programmable LED lighting system (CID Bio-Science, USA), respectively. Light distribution was recorded using JAZ-ULM-200 spectrometer (Ocean Optics, FL, USA) and converted with Spectrasuite software (Ocean Optics) to $\mu \mathrm{mol}$ $\mathrm{m}^{-2} \mathrm{~s}^{-1}$ (Figure 1) and uniformity was verified by measuring the light intensity at five points of each light treatment at the canopy level (Table 1). 


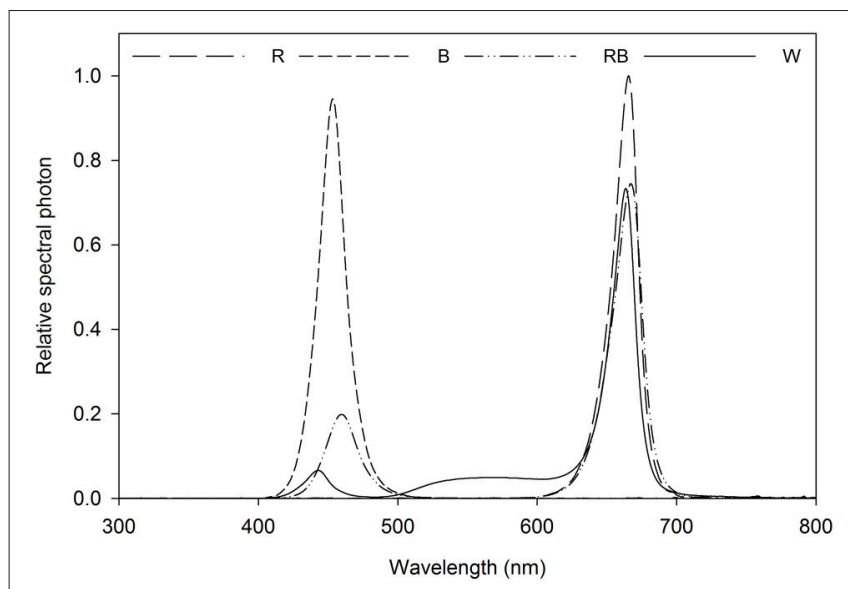

FIGURE 1 | Relative spectral distribution of the light treatments: Red (R), Blue (B), Red/Blue (3:1) (RB) and white (W). Spectrum was measured the plant canopy level with a JAZ spectrometer (Ocean Optics, FL, US).

TABLE 1 | Light treatment with different light spectrum, average PPF per treatment, phytochrome photostationary state $\left(P_{f r} / P_{\text {total }}\right)$.

\begin{tabular}{lcccc}
\hline Parameter & R & B & RB & W \\
\hline PPFD $(400-700 \mathrm{~nm})$ & $97.4 \pm 4.2$ & $100.1 \pm 1.2$ & $100.3 \pm 3.6$ & $97.6 \pm 4.7$ \\
$\left(\mu \mathrm{mol} \mathrm{m}{ }^{-2} \mathrm{~s}^{-1}\right)^{\mathrm{a}}$ & & & & \\
$\mathrm{P}_{\text {fr }} / \mathrm{P}_{\text {total }} \mathrm{b}^{\mathrm{b}}$ & 0.884 & 0.489 & 0.874 & 0.879 \\
$\% \mathrm{~B}$ & 0 & $100 \%$ & $25 \%$ & $7 \%$ \\
\hline
\end{tabular}

${ }^{a}$ Mean \pm standard deviation, $n=5$.

${ }^{b}$ Phytochrome photostationary state calculated according to Sager et al. (1988).

The plants were grown for 8 weeks and then the second or third leaf counting from the apex (fully expanded leaves that developed entirely under the given light quality) were selected for the measurements. All measurements were performed in four replications per treatment and per plant species.

\section{Leaf Anatomy}

Leaf segments of $2 \times 2 \mathrm{~cm}$ of the central leaf blade next to main vein were excised and fixed for at least $24 \mathrm{~h}$ in a formaldehydebased fixative (FAA). Then, leaf segments were dehydrated using a series graded concentration ethanol, embedded in paraffin, and sectioned at thickness of $12 \mu \mathrm{m}$ with a microtome (R. Jung AG, Heidelberg, Germany). The sections were deparaffinized with xylene and rehydrated with graded ethanol, stained with safranin for $30 \mathrm{~min}$ and fast green for $30 \mathrm{~s}$. Stained sections were sealed with Canadian balsam and examined with a bright field microscopy (IX81, Olympus, Japan) at magnification 400x. Images of the cross sections were taken and measured for widths of whole-leaf, palisade mesophyll, spongy mesophyll and abaxial and adaxial epidermal tissues with Image (ImageJ $1.48 \mathrm{v}, \mathrm{NIH}$, USA).

\section{Leaf Hydraulic Conductivity}

The hydraulic conductance of whole leaves ( $\mathrm{K}_{\text {leaf }}$ ) was performed using a high pressure flowmeter method (HPFM) with slight modifications (Sack et al., 2002). The second or lower fully expanded leaf (depending on the species) was cut next to the petiole stem insertion and immediately placed in a water bath. The petiole was cut under water with a sharp blade to $1 \mathrm{~cm}$ length, then wrapped with parafilm (to ensure good seal between petiole and tubing) and inserted into the silicon tube which was connected to the HPFM hydraulic measurement system as described by Tyree (Tyree et al., 2005). Briefly high pressure water was pressed into the leaf vein, leaves were perfused at 0.3 $\mathrm{MPa}$ with distilled water for around $60 \mathrm{~min}$ until steady-state conditions $( \pm 5 \%)$, the flow rate was recorded and calculated to leaf hydraulic conductance $\left(\mathrm{mmol} \mathrm{m} \mathrm{m}^{-2} \mathrm{~s}^{-1} \mathrm{MPa}^{-1}\right)$. Leaf area was measured afterward with a leaf area meter (Li-Cor 3000, LiCor, USA) to normalize hydraulic measurements by leaf area.

\section{Stomatal Characteristics and Stomatal Conductance}

Stomatal traits were analyzed using a nail polish print method on the leaf abaxial side as describe by Mott et al. (1991). The nail polish layer was removed with a transparent tape and pasted on a glass slide, the slides were observed with a bright field microscopy (IX81, Olympus, Tokyo, Japan) and stomatal density was calculated based on stomatal counts of 12 microscopic fields $\left(25 \mathrm{x}\right.$, microscopic field $0.16 \mathrm{~mm}^{2}$ ) per leaf, ensuring a $95 \%$ confidence level of the results, as the number of stomata per $\mathrm{mm}^{2}$. The stomatal index was calculated as number of stomata/(number of epidermal cells + number of stomata) $\times$ 100 (Kubinova, 1994). The stomatal aperture, width and length was defined as (Chen et al., 2012) and stomatal aperture area was calculated by assuming an oval pore shape. The total stomatal aperture area per unit leaf area $\left(\mathrm{cm}^{2} \mathrm{~m}^{-2}\right)$ was calculated as stomatal average density $\times$ stomatal aperture area.

Stomatal conductance $\left(\mathrm{g}_{\mathrm{s}}\right)$ was measured using a leaf porometer (AP4 porometer, Delta-T Devices, Cambridge, UK). The second/third fully developed leaf (different according to the plant species) was chosen for measurements. Four positions on each leaf were measured and the average result was used as the stomatal conductance of this leaf. C. australis is characterized by narrow leaves, which did not allow a correct measurement of $g_{s}$ by porometry, therefore $g_{s}$ of was estimated based on stomatal characteristics as described by Franks and Farquhar (2001):

$$
g_{s}=\frac{S D D a^{\prime}}{V\left(l+\frac{\pi}{4} \sqrt{\frac{a^{\prime}}{\pi}}\right)}
$$

Where $\mathrm{SD}=$ stomatal density $\left(\mathrm{N} \mathrm{m}^{-2}\right), \mathrm{D}=$ diffusivity of water in air $\left(22^{\circ} \mathrm{C}, 24.5 \times 10^{-6} \mathrm{~m}^{2} \mathrm{~s}^{-1}\right)$, a' = stomatal aperture area $\left(\mathrm{m}^{-2}\right), \mathrm{V}=$ molar volume of air $\left(\mathrm{m}^{3} \mathrm{~mol}^{-1}\right), \mathrm{l}=$ depth of stomatal pore $\left(\mathrm{m}, 12 \times 10^{-6} \mathrm{~m}\right.$ for C. australis, mean of 10 replicates).

\section{Chlorophyll a Fluorescence}

The leaf chlorophyll fluorescence measurement was conducted using a PAM-2500 portable chlorophyll fluorometer (Walz, Effeltrich, Germany). The second fully expanded leaf of $S$. speciosa and the third leaf for C. australis and F. benjamina 
were selected for this measurement. Leaves were dark adapted with a leaf clip for $20 \mathrm{~min}$, then a $0.6 \mathrm{~s}$ saturating light pulse $\left(3,450 \mu \mathrm{mol} \mathrm{m} \mathrm{s}^{-2} \mathrm{~s}^{-1}\right)$ was given to obtain the $\mathrm{F}_{\mathrm{m}}$ and $\mathrm{F}_{0}$. After that, the leaf was light adapted with 5 min continuous actinic light (100 $\mu \mathrm{mol} \mathrm{m} \mathrm{m}^{-2} \mathrm{~s}^{-1}$, similar as the growing condition) with saturating pulses every $25 \mathrm{~s}$, after that, the maximum light adapted fluorescence $\left(\mathrm{F}_{\mathrm{m}}{ }^{\prime}\right)$ and steady state fluorescence $\left(\mathrm{F}_{\mathrm{S}}\right)$ were recorded. The maximum photochemical efficiency of PSII $\left(\mathrm{F}_{\mathrm{v}} / \mathrm{F}_{\mathrm{m}}\right)$ was calculated as $\mathrm{F}_{\mathrm{v}} / \mathrm{F}_{\mathrm{m}}=\left(\mathrm{F}_{\mathrm{m}}-\mathrm{F}_{0}\right) / \mathrm{F}_{\mathrm{m}}$ (Genty et al., 1989). Then, the actinic light was turned off and a farred pulse was applied to obtain the minimal fluorescence after the PSI excitation $\left(\mathrm{F}_{0}^{\prime}\right)$. PSII operating efficiency $\left(\Phi_{\mathrm{PSII}}\right)$ was calculated as $\Phi_{\mathrm{PSII}}=\left(\mathrm{F}_{\mathrm{m}}{ }^{\prime}-\mathrm{F}_{\mathrm{s}}\right) / \mathrm{F}_{\mathrm{m}}{ }^{\prime}$ and $\mathrm{qP}$ was calculated as $\mathrm{qP}=\left(\mathrm{F}_{\mathrm{m}}{ }^{\prime}-\mathrm{F}_{\mathrm{s}}\right) /\left(\mathrm{F}_{\mathrm{m}}{ }^{\prime}-\mathrm{F}_{0}{ }^{\prime}\right) ; \mathrm{NPQ}$, which is proportional to the rate constant of the thermal energy dissipation, was estimated as $N P Q=\left(F_{m}-F_{m}{ }^{\prime}\right) / F_{m}{ }^{\prime}$ (Baker, 2008). The electron transport rate $(\mathrm{ETR})$ was calculated as $\mathrm{ETR}=\Phi_{\mathrm{PSII}} \times \mathrm{PAR} \times 0.84 \times 0.5$, where the absorbed photon energy (PAR) is assumed to be equally distributed between PSI and PSII and 0.84 is the assumed light absorbance of the leaf.

\section{Pigments Content}

Leaf chlorophyll content was determined according to Lichtenthaler and Buschmann (2001). One Hundred Fifty milligrams fresh leaf was grinded using liquid nitrogen and extracted in $80 \%$ acetone overnight at $-20^{\circ} \mathrm{C}$. Absorbance at 470 $\mathrm{nm}\left(\mathrm{A}_{470}\right), 645 \mathrm{~nm}\left(\mathrm{~A}_{645}\right)$, and $663 \mathrm{~nm}\left(\mathrm{~A}_{663}\right)$ was measured with a spectrophotometer (Infinite 200, Tecan Group Ltd., Switzerland) and the pigment contents were calculated from the following equations: $\mathrm{Chl} a=12.25 \times \mathrm{A}_{663}-2.79 \times \mathrm{A}_{645}$; Chl $b=21.50 \times \mathrm{A}_{645}-5.10 \times \mathrm{A}_{663}$, and Carotenoids $=(1000 \times$ $\left.\mathrm{A}_{470}-1.82 \times \mathrm{Chl} a-85.02 \times \mathrm{Chl} b\right) / 198$.

\section{Plant Growth Measurements}

The second fully expanded leaf area counting from the apex was measured using a leaf area meter (Li-Cor 3000, Li-Cor, USA) this in four replicates. Four plants per treatment and cultivar were used for the biomass measurements. After aerial fresh weight (FW) determination plants were oven-dried at $85^{\circ} \mathrm{C}$ for 3 days until a constant mass was reached to determine dry weight (DW).

\section{Statistical Analysis}

Data are presented as means \pm SE. Data were analyzed for light quality for each species by one-way analysis of variance (ANOVA), after verifying homoscedasticity by Levene's test. Tukey's HSD test was used to compare means at $p<$ 0.05. Correlations between traits were tested using Pearson's correlation coefficients. A regression testing $\mathrm{K}_{\text {leaf }}$ as function of leaf thickness and stomatal conductance was performed. All statistical analyses were conducted using SPSS Statistics 22 (IBM Software, Chicago, USA).

\section{RESULTS}

\section{Biomass and Leaf Characteristics}

In $C$. australis, total aboveground fresh weight was the greatest under $\mathrm{W}$, followed by $\mathrm{B}$ and $\mathrm{RB}$ and significantly decreased under $\mathrm{R}$, similar the dry weight was greatest under $\mathrm{W}$ and declined under R (Figure 2). Biomass (both FW and DW) of F. benjamina and $S$. speciosa were significantly lower under $\mathrm{R}$, while no significant difference between the other light qualities were found.

The three species had very different leaf morphologies (Figure 2, Table 2). C. australis and F. benjamina had relative small leaves, while S. speciosa developed large leaves. B enhanced the leaf area of $F$. benjamina followed by $\mathrm{RB}$ and $\mathrm{W}$ while
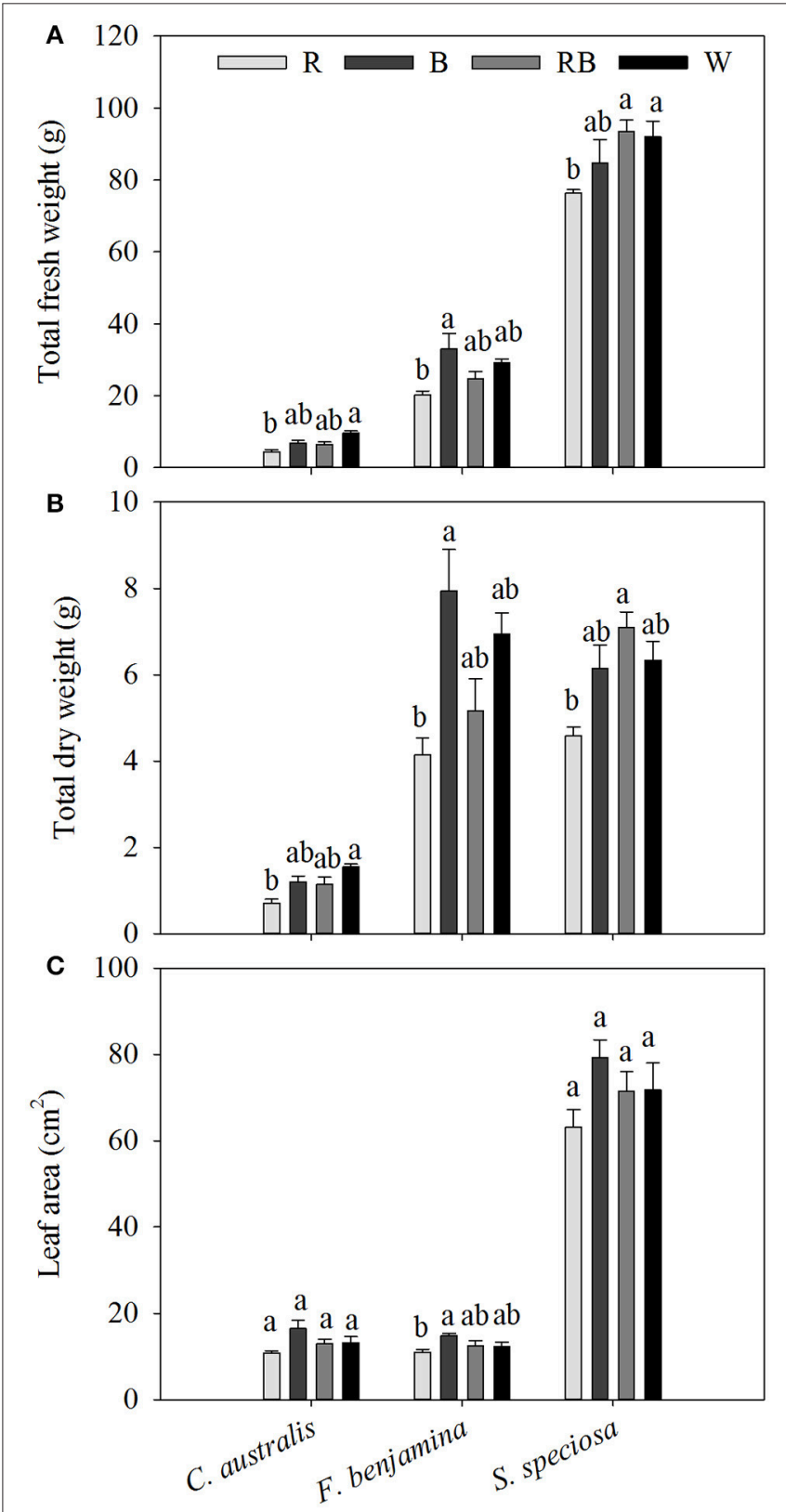

FIGURE 2 | Effects of light quality on total aboveground fresh weight (A), total dry weight (B) and individual leaf area (C) of C. australis, F. benjamina, and S. speciosa. Data are presented as means \pm standard error $(n=4)$. Different letters indicate significant differences between values $(p<0.05)$. 
TABLE 2 | Effect of light quality on the leaf anatomy of leaves of C. australis, F. benjamina, and S. speciosa.

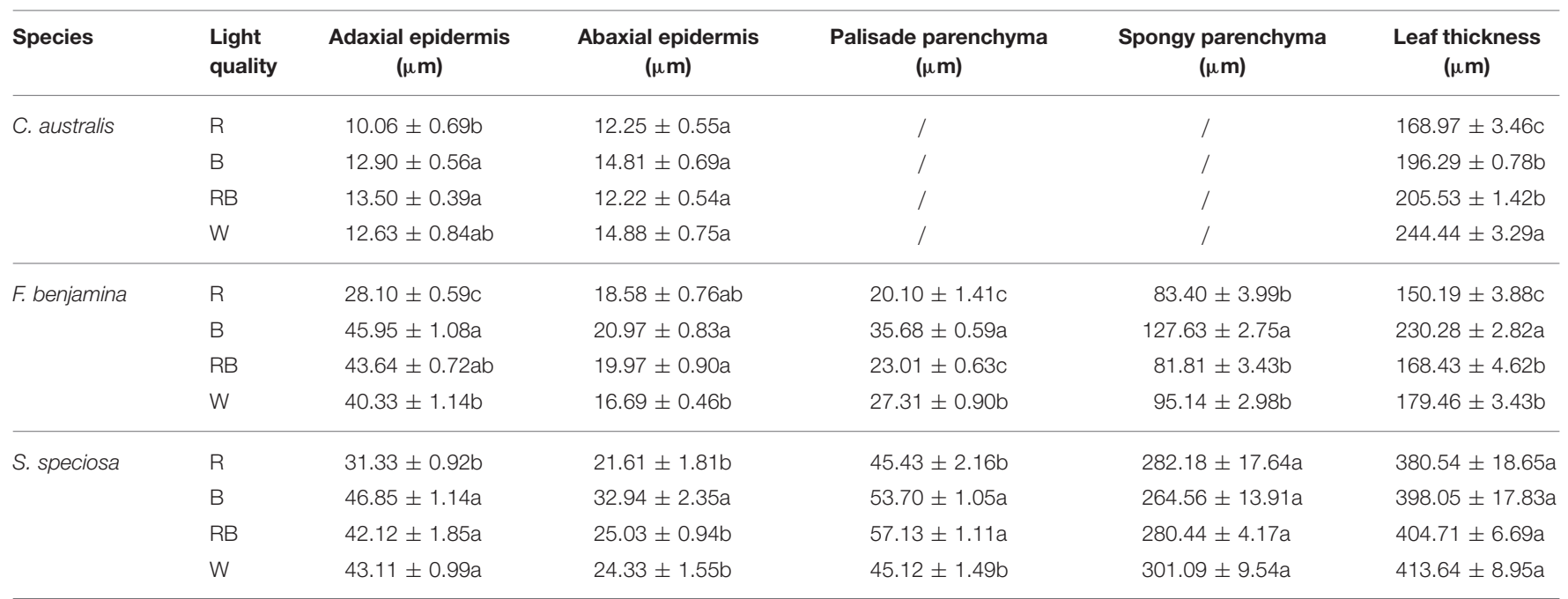

Different letters indicate significant differences between values $(p<0.05)$ for each parameter. Data given as means $\pm S E(n=5)$.

it significantly decreased under R. B tended to increase the individual leaf area in both $C$. australis and S. speciosa though this was not significant ( $P=0.070$ and 0.183 , respectively).

Leaf thickness in C. australis was highest under $\mathrm{W}$ followed by $\mathrm{RB}$ and $\mathrm{B}$ while the thinnest leaves were found under $\mathrm{R}$ (Table 2, Figure 3). As C. australis is a monocot, the leaf anatomy is isobilateral and the mesophyll is hardly differentiated into palisade and spongy parenchyma cells. Therefore, only the adaxial and abaxial epidermal thickness was measured which contribute, respectively, $6.1 \pm 0.23$ and $6.7 \pm 0.26 \%$ of the total leaf thickness. Abaxial epidermis was not affected by light quality while the thinnest adaxial epidermis was found under $\mathrm{R}$ while $\mathrm{B}$ and RB had the thickest epidermal cells.

Leaf thickness in F. benjamina was greatest under B, lower under $\mathrm{RB}$ and $\mathrm{W}$ while it was significantly thinner under $\mathrm{R}$ (Table 2). F. benjamina has evergreen glossy leaves and the adaxial and abaxial epidermis contribute, respectively, $21.8 \pm$ 1.0 and $10.6 \pm 0.5 \%$ to the leaf thickness. Especially the adaxial epidermis is strongly reduced under $\mathrm{R}$ followed by $\mathrm{W}$. The effect on the abaxial epidermis is not as strong though also here the thinnest cell layers are under $\mathrm{R}$ and $\mathrm{W}$. The leaf thickness difference is strongly influenced by the mesophyll. In absolute value the palisade parenchyma is highest under B although it represents only $15.5 \%$ of the total leaf thickness while the palisade layer is, respectively, $26 \%$ under RB and $24 \%$ under W. B also strongly enhances the spongy parenchyma while it is not affected by the other light qualities. In S. speciosa, leaf thickness was not affected by the different light qualities (Table 2). S. speciosa has velvety hairy leaves and the adaxial and abaxial epidermis contribute, respectively, $10.2 \pm 0.5$ and $6.5 \pm 0.4 \%$ to the leaf thickness. Adaxial epidermal thickness was found thinnest under $\mathrm{R}$ while it tended to be thicker under $\mathrm{B}$ though not significant differing from RB and W. Abaxial epidermis was thickest under B. Palisade parenchyma thickness was found lower under $\mathrm{R}$ and $\mathrm{W}$ and significantly greater under $\mathrm{B}$ and $\mathrm{RB}$ while no effect were found for the spongy parenchyma.
Leaf thickness correlated with $\Phi_{\text {PSII }}$ in C. australis $(r=0.855)$ but this correlation was weaker in F. benjamina $(r=0.622)$ while thickness of the palisade parenchyma correlated moderately with $\Phi_{\text {PSII }}$ in S. speciosa $(r=0.674)$.

\section{Leaf Hydraulic Conductance}

Light quality tended to influence the leaf hydraulic conductance of the selected ornamentals though effects were not significant (Figure 4). In C. australis $\mathrm{K}_{\text {leaf }}$ was lowest under B and slightly increased under R, RB, and W. In F. benjamina and S. speciosa $\mathrm{K}_{\text {leaf }}$ was lowest under $\mathrm{R}$ and highest under $\mathrm{B}$. On average $\mathrm{K}_{\text {leaf }}$ was highest in C. australis, followed by F. benjamina and quite low in S. speciosa.

Correlation study between $\mathrm{K}_{\text {leaf }}$ and other leaf characteristics showed positive correlations with leaf thickness and stomatal conductance in F. benjamina and S. speciosa (Figure 6). However, for the monocot $C$. australis, a negative trend with stomatal conductance was found and no correlation with leaf thickness.

\section{Stomatal Characteristics and Stomatal Conductance}

The effects of light quality on the stomatal characteristics are given in Table 3. The aperture length was not affected by light quality, this for the three species. An increase of aperture area was found in C. australis under B, while no effects were found in F. benjamina and S. speciosa. The width/length ratio was not affected by light quality (data not shown). Total aperture area per unit leaf area was not affected by light quality though it tended to be lower under R for F. benjamina and S. speciosa. Stomatal index and density were significantly affected by the light quality treatments. In C. australis stomatal index decreased under $\mathrm{R}$ though density was not affected. C. australis also showed the highest stomatal density of the studied ornamentals, as it ranged between $274.75 \mathrm{~N}^{\circ} \mathrm{mm}^{-2}$ under $\mathrm{B}$ up to $325.10 \mathrm{~N}^{\circ} \mathrm{mm}^{-2}$ under R. Likewise a high density of epidermal cells per unit leaf area was present but B significantly reduced the number of epidermal cells 

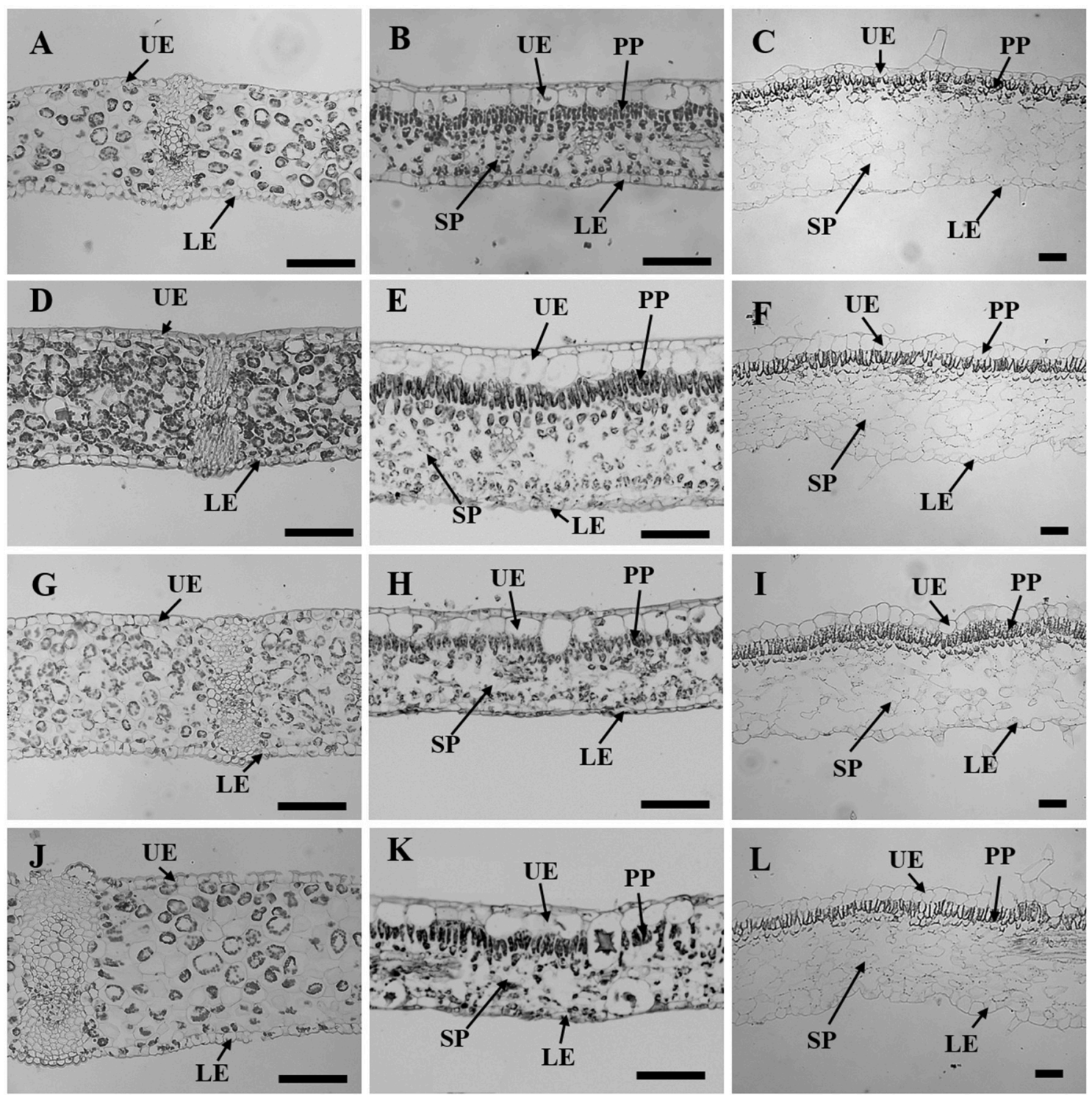

FIGURE 3 | Leaf sectioning anatomy of C. australis (left panel), F. benjamina (middle panel), and S. speciosa (right panel) developed under Red light (A-C), Blue light (D-F), Red with Blue (G-I) and White (J-L). Black bar = $100 \mu \mathrm{m}$. UE, upper epidermis; LE, lower epidermis; PP, palisade parenchyma; SP, spongy parechyma.

(Table 3). In F. benjamina, both $\mathrm{R}$ and $\mathrm{B}$ gave the lowest stomatal index while the highest index was found under W; the stomatal density was lowest under R and highest under W. In S. speciosa both the highest stomatal density and index were found under $\mathrm{B}$ and $\mathrm{W}$ and the lowest under $\mathrm{R}$.

The stomatal conductance of the ornamentals was differentially affected by the different light qualities (Figure 4). For C. australis, no effects were noted on the stomatal conductance with respect to increasing B. For both F. benjamina and $S$. speciosa stomatal conductance increased with increasing $\mathrm{B}$ when comparing $\mathrm{R}, \mathrm{RB}$, and $\mathrm{B}$. However, multispectral $\mathrm{W}$ yielded the highest stomatal conductance in both species. A strong correlation of stomatal density $(r=0.979)$ with $g_{\mathrm{s}}$ and stomatal index $(r=0.995)$ with $g_{s}$ was found in S. speciosa.

\section{Chlorophyll a Fluorescence}

Effects of light quality on chlorophyll fluorescence parameters of the studied ornamentals are given in Table 4. The maximum quantum efficiency $\mathrm{F}_{\mathrm{v}} / \mathrm{F}_{\mathrm{m}}$, was influenced by the applied light quality and overall we saw a lower value of $\mathrm{F}_{\mathrm{v}} / \mathrm{F}_{\mathrm{m}}$ for $\mathrm{R}(P=$ 0.003 ). For $C$. australis, the lowest value was observed under $R$, $\mathrm{F}_{\mathrm{v}} / \mathrm{F}_{\mathrm{m}}$ increased under $\mathrm{W}$ and $\mathrm{RB}$ while $\mathrm{B}$ gave the highest $\mathrm{F}_{\mathrm{v}} / \mathrm{F}_{\mathrm{m}}$ value. For F. benjamina and S. speciosa $\mathrm{F}_{\mathrm{v}} / \mathrm{F}_{\mathrm{m}}$ declined under $\mathrm{R}$ compared to the other spectral qualities.

$\Phi_{\text {PSII }}, \mathrm{qP}$ and ETR showed a similar reaction to the light quality treatments. For both C. australis and S. speciosa the lowest values for $\Phi_{\mathrm{PSII}}$ were observed under R. For $F$. benjamina, $\Phi_{\mathrm{PSII}}$ was significant higher under $\mathrm{B}$, while $\mathrm{R}$ and $\mathrm{W}$ gave lower values. For both C. australis and S. speciosa highest $\mathrm{qP}$ were found for 

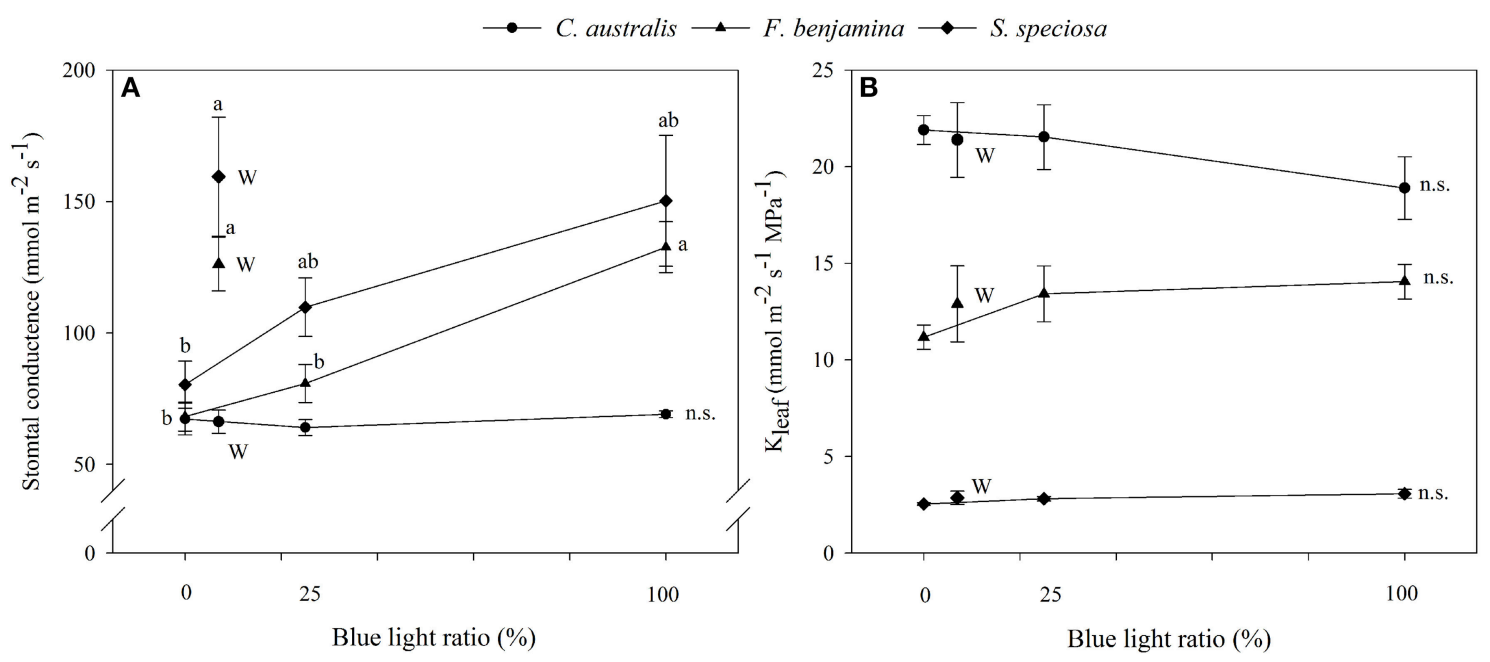

FIGURE 4 | Effects of blue light ratio on stomatal conductance (A) and leaf hydraulic conductance (B) of C. australis, F. benjamina, and S. speciosa. Data are presented as means \pm standard error $(n=4)$. Different letters indicate significant differences between values $(p<0.05)$ and n.s. indicates no significant differences. $\mathrm{W}$ indicates the multispectral white treatment.

TABLE 3 | Effect of light quality on the stomatal characteristics of leaves of C. australis, F. benjamina, and S. speciosa.

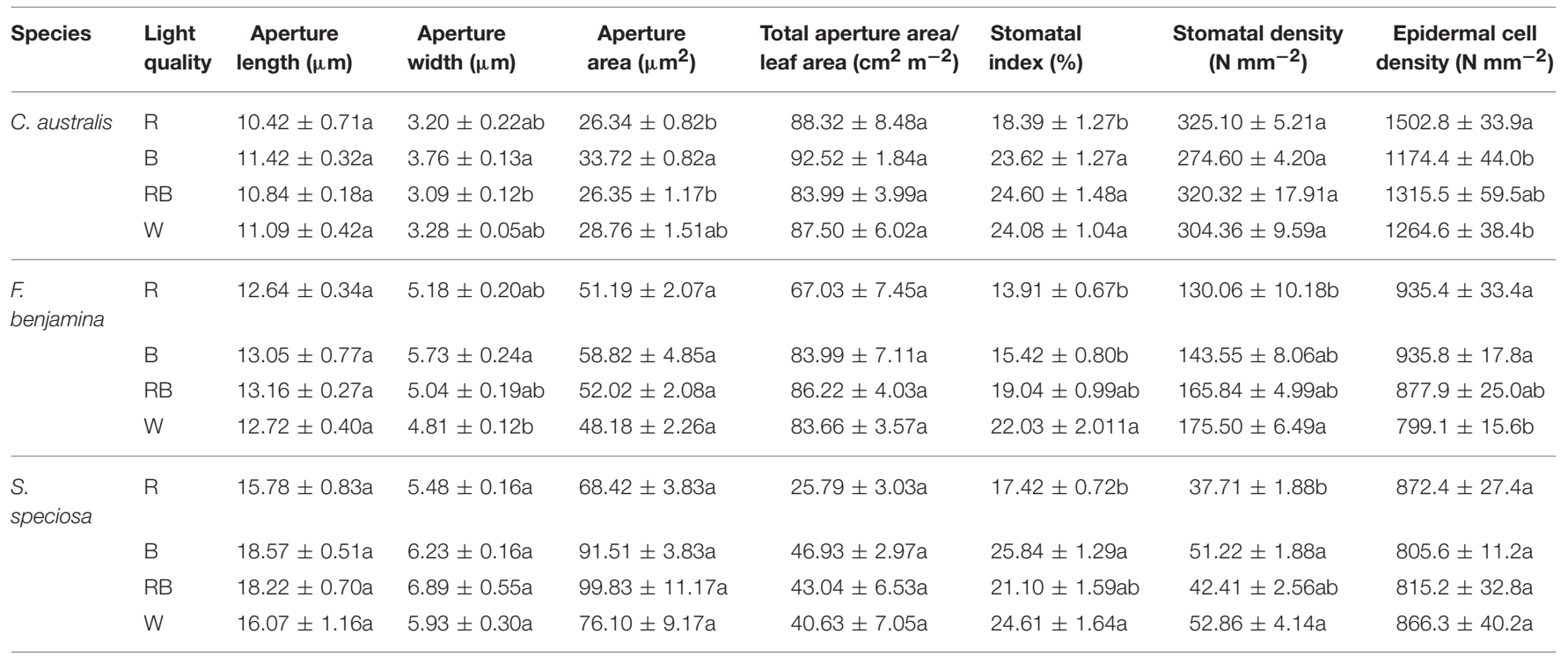

Different letters indicate significant differences between values $(p<0.05)$ for each parameter. Data given as means $\pm S E(n=5)$.

$\mathrm{RB}$ and $\mathrm{W}$ while no effect of light quality was found for $F$. benjamina.

NPQ significantly increased under $B$ followed by $R B$ compared to $\mathrm{W}$ and $\mathrm{R}$ in $C$. australis, while for $S$. speciosa, it significantly increased under $\mathrm{R}$ and $\mathrm{W}$ followed by $\mathrm{B}$ compared with RB. However, for F. benjamina, no effect of light quality was found on NPQ $(P=0.117)$, though it tended to be higher under W.

\section{Leaf Pigment Contents}

The total pigment content was different between the species (Figure 5). In F. benjamina, the total chlorophyll content ranged from 1.102 to $1.338 \mathrm{mg} \mathrm{g}^{-1}$, while it was 0.395 to $0.668 \mathrm{mg}$ $\mathrm{g}^{-1}$ and 0.395 to $0.668 \mathrm{mg} \mathrm{g}^{-1}$ for S. speciosa and C. australis, respectively. The carotenoids were higher in C. australis (0.103$0.138 \mathrm{mg} \mathrm{g}^{-1}$ ) and F. benjamina (0.100-0.190 $\mathrm{mg} \mathrm{g}^{-1}$ ) followed by $S$. speciosa $\left(0.050-0.103 \mathrm{mg} \mathrm{g}^{-1}\right)$. Overall the total chlorophyll content was not significantly affected by the light quality $(P=$ 0.468) though there were species differences (Figure 5). In $C$. australis the highest $\mathrm{Chl} a, \mathrm{Chl} b$, and $\mathrm{Chl} a / b$ was found under $\mathrm{RB}$ and the lowest content was found under $\mathrm{R}$, while no significant effect on carotenoid content was present. In F. benjamina, no significant effects of light quality on chlorophyll and carotenoid content were observed. Blue light yielded the highest $\mathrm{Chl} a, \mathrm{Chl}$ $a / b$, and carotenoid content in S. speciosa leaves followed by R. The lowest $\mathrm{Chl} a, \mathrm{Chl} a / b$, and carotenoid content were found for 
TABLE 4 | Effect of light quality on chlorophyll fluorescence parameters: $F_{\mathrm{V}} / F_{\mathrm{m}}, \Phi_{\mathrm{PSSI}}, \mathrm{QP}, \mathrm{NPQ}$, and ETR of $C$. australis, F. benjamina, and $S$. speciosa.

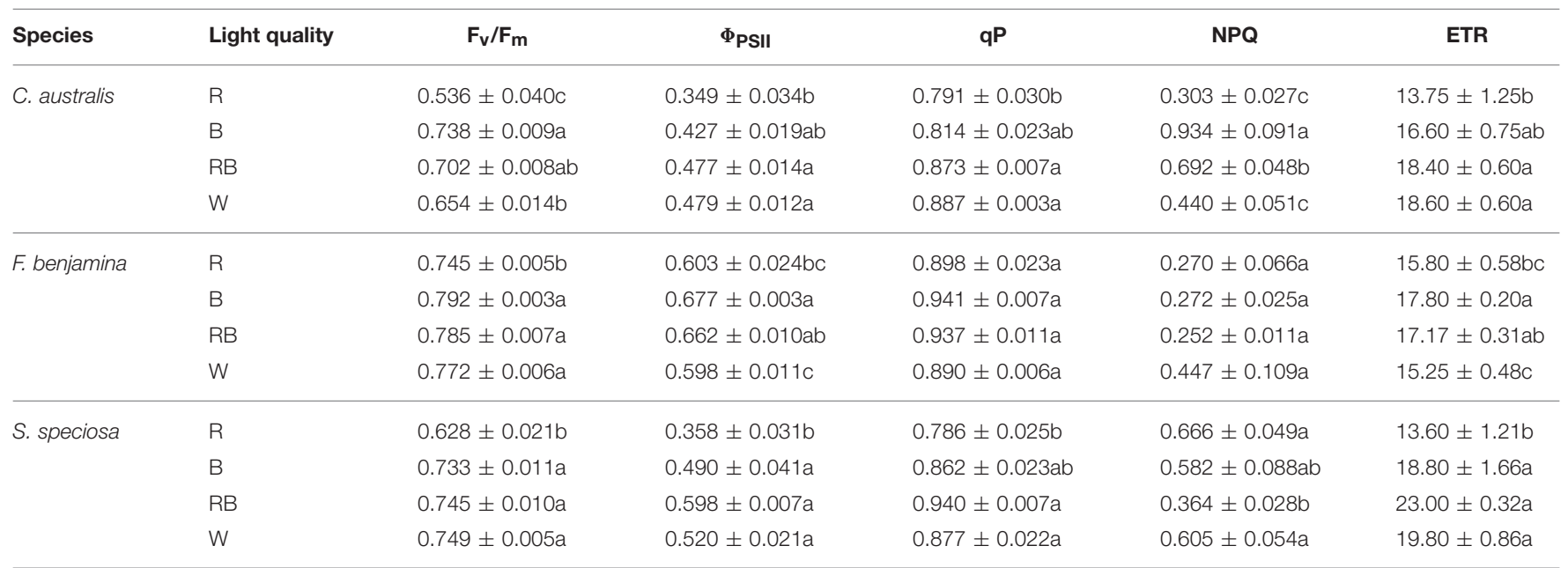

Different letters indicate significant differences between values $(p<0.05)$ for each parameter. Data given as means $\pm S E(n=5)$.

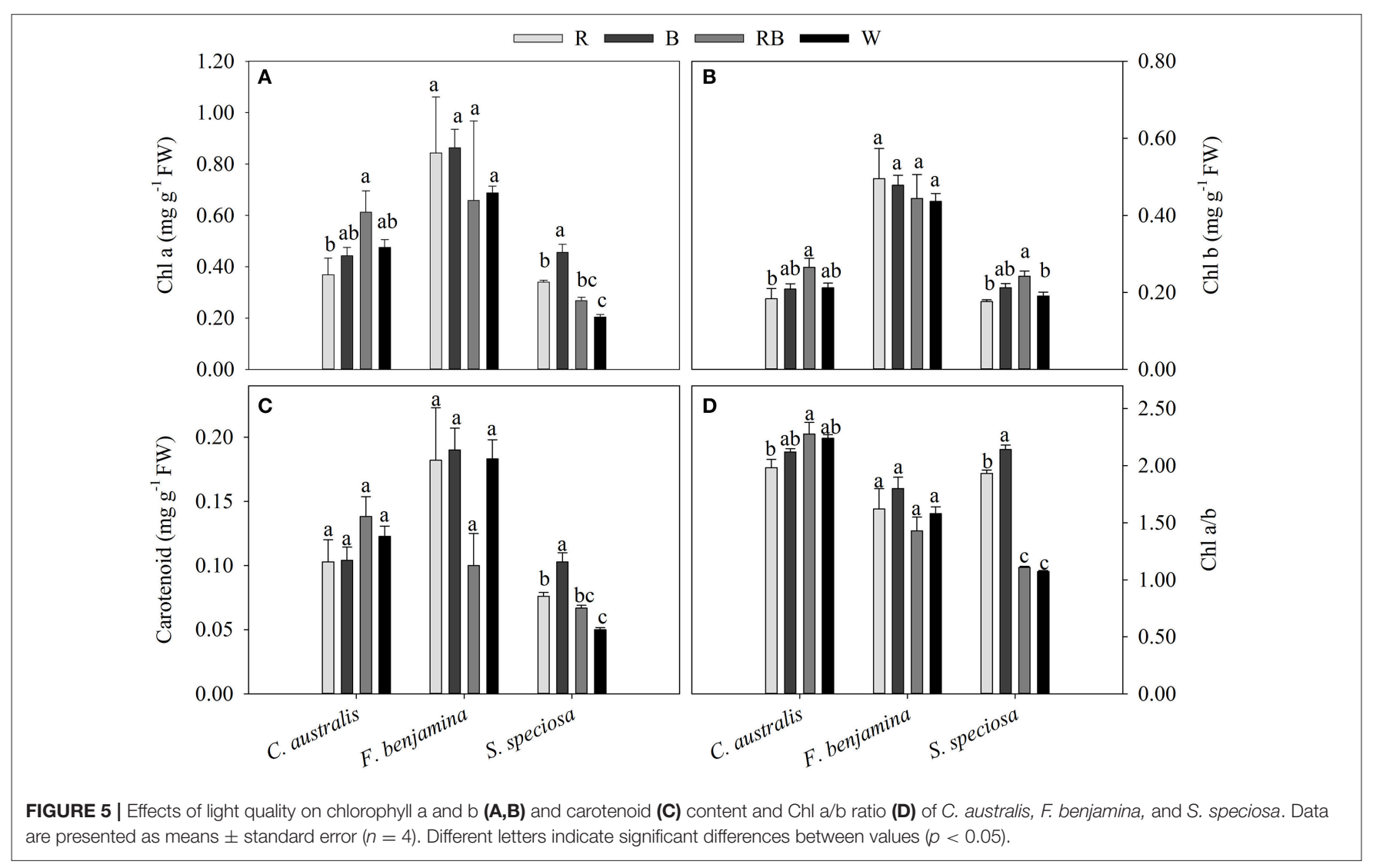

$\mathrm{W}$, this treatment lead to a decrease of 55 and $51 \%$ for Chl $a$ and carotenoids compared to B.

\section{DISCUSSION}

Leaf photosynthesis requires the interception of light. Light inside the leaf is influenced by the wavelength, the light level and the angle of the incident light (Brodersen and Vogelmann, 2010) as well as by the leaf anatomy. Light is absorbed by chloroplasts while passing through the palisade and spongy mesophyll. The vertically elongated palisade cells minimize light scattering, allowing a deeper penetration, while spongy tissue enhances the light capture by scattering light (Evans, 1999). F. benjamina and S. speciosa are both dicots with palisade and spongy mesophyll. F. benjamina reacted strongly to B not only in total leaf thickness but also by an increasing effect on all anatomical structures. 
Reduction or absence of blue light decreased leaf thickness and respective anatomical structures and this was most pronounced for monochromatic $\mathrm{R}$. This reaction reflects the observations on pepper (Schuerger et al., 1997) and wheat (Goins et al., 1997) where increased levels of $\mathrm{B}$ to $\mathrm{R}$ increased the palisade and spongy mesophyll thickness. In S. speciosa, however, total leaf thickness was not affected but a reorganization of the mesophyll resulting in a higher percentage of palisade parenchyma (16\%) was observed for $\mathrm{B}$ and $\mathrm{RB}$ while for $\mathrm{W}$ and $\mathrm{R}$ the palisade parenchyma averaged $13 \%$ of the total mesophyll. The greater cell surface area per unit of mesophyll volume makes palisade tissue a more efficient structure in term of photosynthesis than spongy mesophyll (Evans, 1999). For the monocot C. australis, the full spectrum $\mathrm{W}$ resulted in the thickest leaves though comparing $\mathrm{R}$ with $\mathrm{RB}$ and $\mathrm{B}$ also indicated the favorable effect of $\mathrm{B}$ on leaf thickness.

Schuerger et al. (1997) also reported an effect of blue light on secondary xylem formation in peppers suggesting an effect of light quality on water translocation. Buckley et al. (2015) suggested that greater leaf thickness should contribute to a higher leaf conductance $\left(\mathrm{K}_{\text {leaf }}\right)$ given the greater number of parallel pathways for horizontal transport to the sites of evaporation, if those sites are distributed throughout the leaf. More specifically the maximal $\mathrm{K}_{\text {leaf }}$ correlated with palisade thickness, and palisade/spongy mesophyll ratio for tropical rainforest tree species (Sack and Frole, 2006). $K_{\text {leaf }}$ of bur oak enhanced under blue and green light compared to other wavelengths (Voicu et al., 2008). However, in bur oak one focused mainly on short term responses to light quality while this study was conducted on leaves that were formed under a given spectral light quality. Therefore, effects on $\mathrm{K}_{\text {leaf }}$ can be attributed to differences in the development of leaf mesophyll and veins. $\mathrm{K}_{\text {leaf }}$ varied strongly between the studied species and was much greater in C. australis than in S. speciosa, while $F$. benjamina was intermediate (Figure 4). This variation in $\mathrm{K}_{\text {leaf }}$ among species is reported by several authors and can fluctuate up to 65-fold across plant species (Sack and Holbrook, 2006; Brodribb et al., 2012; Buckley, 2015). Under B, $\mathrm{K}_{\text {leaf }}$ of the dicots F. benjamina and S. speciosa tended to be higher. This is in agreement with Savvides et al. (2012), who were the first to report that cucumber leaves that developed under B and RB had a higher $\mathrm{K}_{\text {leaf. }}$. Furthermore, $\mathrm{K}_{\text {leaf }}$ correlated with thickness of leaf $(r=$ $0.79)$ and palisade parenchyma $(r=0.78)$ in F. benjamina as well as in S. speciosa ( $r=0.46$ and $r=0.50$, respectively) (Figure 6). In contrast, we found quite different results in the monocot $C$ australis, where $\mathrm{K}_{\text {leaf }}$ was independent of leaf thickness. The leaf anatomical structure of monocots makes that water in the major vein exits into surrounding tissue of bundle sheath cells instead of the minor veins (Xiong et al., 2015). We did not quantify leaf venation in this study although it might influence the leaf hydraulic conductance (Nardini et al., 2003). However, it is more likely that the small variations in both $\mathrm{K}_{\text {leaf }}$ and leaf thickness explain the absence of a relation in C. australis. $\mathrm{K}_{\text {leaf }}$ and $\mathrm{g}_{s}$ correlated positively ( $r=0.48$ and 0.72 , respectively) in both $F$. benjamina and $S$. speciosa which agrees with previous observations (Augé et al., 2008; Brodribb et al., 2012; Savvides et al., 2012).

Stomatal development is influenced by light quality which in turn will influence the conductance $\left(\mathrm{g}_{\mathrm{s}}\right)$ of air through the leaf mesophyll and stomata. Blue light increased the stomatal density of chrysanthemum (Kim et al., 2004) and this was also observed in F. benjamina and S. speciosa. Moreover, additional blue light increased the stomatal index in all the studied species and both parameters (stomatal index and stomatal density) were highly correlated in F. benjamina and S. speciosa ( $r=$ 0.99 and 0.97 , respectively). These results reflect the effect of blue light on the development of stomata, which is mediated through the additive function of CRY1 and CRY2 (Pillitteri and Torii, 2012). Stomatal density and index are not correlated in C. australis which is due to the lower stomatal density under blue (Table 3). In C. australis the total number of epidermal cells per unit of area was also reduced under B in comparison
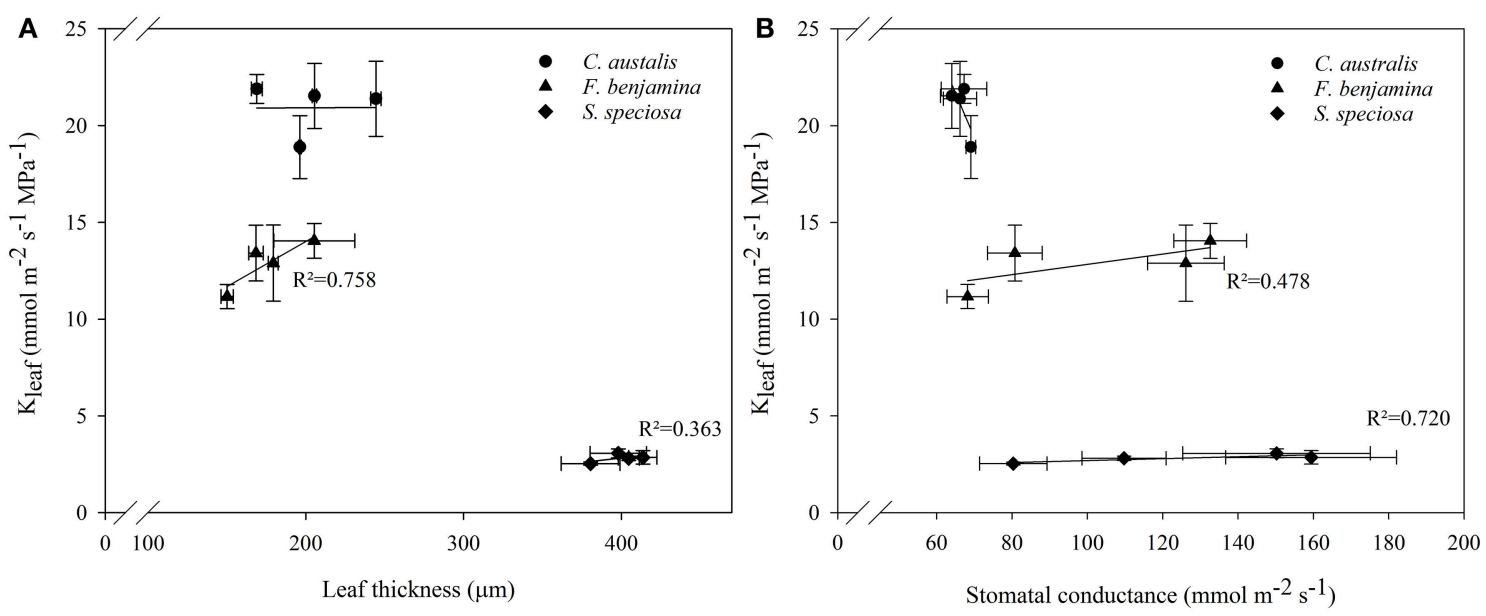

FIGURE 6 | Correlations between leaf thickness and $\mathrm{K}_{\text {leaf }}(\mathbf{A})$ and stomatal conductance and $\mathrm{K}_{\text {leaf }}$ (B) of C. australis, F. benjamina, and $S$. speciosa under different light qualities. Values presents the mean of four replicates with standard errors $(n=4)$. 
with monochromatic R, indicating larger epidermal cells under B. Likewise in Pelargonium leaves the positive effect of blue light on the elongation of epidermal cells was shown (Fukuda et al., 2008).

However, not only the stomatal density but the additive effect of the stomatal aperture influences the stomatal conductivity. It is well known that blue light affects stomatal opening through the photoreceptors phototropin and cryptochrome (Liscum et al., 2003; Shimazaki et al., 2007; Boccalandro et al., 2012). As a result of this blue light signaling, increased stomatal conductance if blue is added to red might be expected. Indeed, we found a positive effect if $\mathrm{B}$ was added to the $\mathrm{R}$ spectrum on the stomatal conductance in F. benjamina and S. speciosa (Figure 4). Likewise, blue light or addition of $B$ to the spectrum enhanced the total aperture area per unit of leaf area in both $F$. benjamina and S. speciosa (Table 3) even though the correlations with $g_{s}$ were not significant ( $r=0.61$ and 0.79 , respectively). In cucumber, the decline of stomatal conductance under monochromic green, yellow and red light correlated also with reduced photosynthesis (Wang et al., 2009). However, we did not find significant correlations between $\mathrm{g}_{\mathrm{s}}$ and $\Phi_{\text {PSII }}$ in $F$. benjamina and $S$. speciosa. The lower light intensities in this study $(100 \mu \mathrm{mol}$ $\mathrm{m}^{-2} \mathrm{~s}^{-1}$ compared to $350 \mu \mathrm{mol} \mathrm{m} \mathrm{m}^{-2} \mathrm{~s}^{-1}$ in cucumber) may indicate that we were still below the threshold of $g_{s}$ to limit photosynthesis.

Chlorophyll content directly influences the photosynthetic potential as well as the primary production (Curran et al., 1990; Gitelson et al., 2003). Also the chlorophyll content is affected by the light quality and several studies showed the beneficial effect of blue in the light spectrum (Sæbø et al., 1995; Hoffmann et al., 2015). Long-term exposure of leaves to blue light enhances the 5-aminolevulinic acid synthesizing activity (Kamiya et al., 1983) which in turn mediates the biosynthesis of all tetrapyrroles such as hemes and chlorophylls. Also in our study B or RB was favorable for chlorophyll content in S. speciosa and C. australis though this effect was not very strong. For F. benjamina no effects on chlorophyll content were found. This differential response might be due to species effects as also Lin and Hsu (2004) found no effect on pigment content in lettuce leaves.

Different wavelengths penetrate differently into the leaf, blue and red are efficiently absorbed close to the surface, whereas green light contributes more to photosynthesis in deeper leaf layers (Sun et al., 1998; Brodersen and Vogelmann, 2010). In spinach leaves blue light was almost completely absorbed at 300 $\mu \mathrm{m}$ leaf depth while red tailored to $400 \mu \mathrm{m}$ and green light to $600 \mu \mathrm{m}$ leaf depth (Evans, 1999). This reflects the more effective absorption of blue light by chlorophyll (Terashima et al., 2009). Thicker leaves and thicker palisade parenchyma will result in a better absorbance and therefore higher photosynthetic yield (Hanba et al., 2002; Haliapas et al., 2008; Shengxin et al., 2016). The decrease in leaf mesophyll thickness by red light led to a lower photosynthetic yield and photochemical quenching (Tables 2, 4), so leaf thickness did contribute to the higher photosynthetic performance under $\mathrm{B}$ and $\mathrm{RB}$ in this study. The reduced $\Phi_{\text {PSII }}$ in $F$. benjamina under W (leaf thickness $=179.46 \mu \mathrm{m}$ ) compared to B (leaf thickness $=230.28 \mu \mathrm{m}$ ) might be explained by the partial absorbance of the green wavelengths which were not captured by the photosynthetic pigments (Fankhauser and Chory, 1997) though we did not observe this in the monocot species, C. australis.

Irrespective of the penetration depths of light the applied light quality strongly influenced the photosynthetic efficiency $\left(\mathrm{F}_{\mathrm{v}} / \mathrm{F}_{\mathrm{m}}^{\prime} \Phi_{\mathrm{PSII}}\right)$ and $\mathrm{R}$ had a significant negative effect in the three species. This negative effect of monochromatic $\mathrm{R}$ was already reported in cucumber (Wang et al., 2009; Savvides et al., 2012), despite the fact that $\mathrm{R}$ coincides with the absorbance peak of chlorophyll and is known for its higher relative quantum efficiency than B in the instantaneous photosynthetic response (McCree, 1971). Tennessen et al. (1994), however, showed that long term monochromatic R causes an imbalance of photons available to Photosystem I and Photosystem II. Long term absence of blue light reduces the photosynthetic performance which is known as the "red light syndrome" (Trouwborst et al., 2016). This leads to photo-damage as shown by the reduced $\mathrm{F}_{\mathrm{v}} / \mathrm{F}_{\mathrm{m}}$ in this experiment. The effects of additional blue light on photosynthetic performance are integrated in the produced plant biomass which was lowest under $\mathrm{R}$ in the three species while no significantly differences in $B, R B$, and $W$ were found.

\section{CONCLUSION}

We show here for the first time how narrow-band $\mathrm{R}, \mathrm{B}$, and RB modulates leaf morphology, mesophyll anatomy, stomatal formation and hydraulic conductance of leaves of $C$. australis, $F$. benjamina, and S. speciosa in comparison with broad spectrum white-LEDs.

Blue light enhanced leaf thickness in C. australis and $F$. benjamina and palisade parenchyma thickness in $S$. speciosa which suggest a better light absorption for this treatment. Adding blue to red light increased the stomatal index in the three species and enhanced the total aperture per leaf unit in F. benjamina and S. speciosa. Although, $\mathrm{K}_{\text {leaf }}$ was not significantly affected by light quality a moderate correlation between $\mathrm{K}_{\text {leaf }}$ and leaf thickness and $\mathrm{K}_{\text {leaf }}$ and stomatal conductance was found for both dicot species F. benjamina and S. speciosa though not for the monocot C. australis.

Leaves of the three species that developed solely under red light were characterized by a lower $\mathrm{F}_{\mathrm{V}} / \mathrm{F}_{\mathrm{m}}$ and $\Phi_{\mathrm{PSII}}$ indicating a malfunctioning of photosynthesis which also resulted in a lower dry mass production under red. The chlorophyll fluorescence parameters of the other three light treatments $(\mathrm{B}, \mathrm{RB}$, and $\mathrm{W})$ were hardly influenced and also the dry weight production was not influenced.

\section{AUTHOR CONTRIBUTIONS}

LZ and MV conceived and designed the experiments. LZ performed the experiments, analyzed the data and drafted the manuscript, MV critically revised the manuscript. All authors reviewed and approved the final manuscript. 


\section{ACKNOWLEDGMENTS}

We acknowledge the support of the China Scholarship Council (CSC) and a special research fund grant (Bijzonder

\section{REFERENCES}

Augé, R. M., Toler, H. D., Sams, C. E., and Nasim, G. (2008). Hydraulic conductance and water potential gradients in squash leaves showing mycorrhiza-induced increases in stomatal conductance. Mycorrhiza 18, 115-121. doi: 10.1007/s00572-008-0162-9

Baker, N. R. (2008). Chlorophyll fluorescence: a probe of photosynthesis in vivo. Annu. Rev. Plant Biol. 59, 89-113. doi: 10.1146/annurev.arplant.59.032607.092759

Boccalandro, E., Giordano, C. V., Ploschuk, E. L., and Piccoli, P. N. (2012). Phototropins but not cryptochromes mediate the blue light-specific promotion of stomatal conductance, while both enhance photosynthesis and transpiration under. Plant Physiol. 158, 1475-1484. doi: 10.1104/pp.111.187237

Brodersen, C. R., and Vogelmann, T. C. (2010). Do changes in light direction affect absorption profiles in leaves? Funct. Plant Biol. 37, 403-412. doi: 10.1071/FP09262

Brodribb, T. J., Holbrook, N. M., Zwieniecki, M. A., and Palma, B. (2012). Leaf hydraulic capacity in ferns, conifersand angiosperms : conifers in ferns, capacity hydraulic Leaf maxima on photosynthetic impacts. New Phytol. 165, 839-846. doi: 10.1111/j.1469-8137.2004.01259.x

Buckley, T. N. (2015). The contributions of apoplastic, symplastic and gas phase pathways for water transport outside the bundle sheath in leaves. Plant Cell Environ. 38, 7-22. doi: 10.1111/pce.12372

Buckley, T. N., John, G. P., Scoffoni, C., and Sack, L. (2015). How does leaf anatomy influence water transport outside the xylem? Plant Physiol. 168, 1616-1635. doi: 10.1104/pp.15.00731

Chen, Z. H., Hills, A., Batz, U., Amtmann, A., Lew, V. L., and Blatt, M. R. (2012). Systems dynamic modeling of the stomatal guard cell predicts emergent behaviors in transport, signaling, and volume control. Plant Physiol. 159, 1235-1251. doi: 10.1104/pp.112.197350

Curran, P. J., Dungan, J. L., and Gholz, H. L. (1990). Exploring the relationship between reflectance red edge and chlorophyllcontent in slash pine. Tree Physiol. 7:33. doi: 10.1093/treephys/7.1-2-3-4.33

Demotes-Mainard, S., Péron, T., Corot, A., Bertheloot, J., Le Gourrierec, J., Pelleschi-Travier, S., et al. (2016). Plant responses to red and farred lights, applications in horticulture. Environ. Exp. Bot. 121, 4-21. doi: 10.1016/j.envexpbot.2015.05.010

Dutta Gupta, S., and Jatothu, B. (2013). Fundamentals and applications of lightemitting diodes (LEDs) in in vitro plant growth and morphogenesis. Plant Biotechnol. Rep. 7, 211-220. doi: 10.1007/s11816-013-0277-0

Evans, J. R. (1999). Leaf anatomy enables more equal access to light and $\mathrm{CO}_{2}$ between chloroplasts. New Phytol. 143, 93-104. doi: 10.1046/j.1469-8137.1999.00440.x

Fan, X.-X., Xu, Z.-G., Liu, X.-Y., Tang, C.-M., Wang, L.-W., and Han, X. (2013). Effects of light intensity on the growth and leaf development of young tomato plants grown under a combination of red and blue light. Sci. Hortic. 153, 50-55. doi: 10.1016/j.scienta.2013.01.017

Fankhauser, C., and Chory, J. (1997). Light Control of Plant Development. Annu. Rev. Cell Dev. Biol. 13, 203-229. doi: 10.1146/annurev.cellbio.13.1.203

Franks, P. J., and Farquhar, G. D. (2001). The effect of exogenous abscisic acid on stomatal development, stomatal mechanics, and leaf gas exchange in tradescantia virginiana. Plant Physiol. 125, 935-942. doi: 10.1104/pp.125.2.935

Fukuda, N., Fujita, M., Ohta, Y., Sase, S., Nishimura, S., and Ezura, H. (2008). Directional blue light irradiation triggers epidermal cell elongation of abaxial side resulting in inhibition of leaf epinasty in geranium under red light condition. Sci. Hortic. 115, 176-182. doi: 10.1016/j.scienta.2007.08.006

Genty, B., Briantais, J.-M., and Baker, N. R. (1989). The relationship between the quantum yield of photosynthetic electron transport and quenching of chlorophyll fluorescence. Biochim. Biophys. Acta Gen. Subj. 990, 87-92. doi: 10.1016/S0304-4165(89)80016-9
Onderzoeksfonds, BOF) of Ghent University. The authors would like to thank Niels De Baerdemaeker, Laboratory of Plant Ecology, Ghent University for his kind help in learning leaf hydraulic conductance measurements.

Gitelson, A. A., Gritz, Y., and Merzlyak, M. N. (2003). Relationships between leaf chlorophyll content and spectral reflectance and algorithms for non-destructive chlorophyll assessment in higher plant leaves. J. Plant Physiol. 160, 271-282. doi: 10.1078/0176-1617-00887

Goins, G. D., Yorio, N. C., Sanwo, M. M., and Brown, C. S. (1997) Photomorphogenesis, photosynthesis, and seed yield of wheat plants grown under red light-emitting diodes (LEDs) with and without supplemental blue lighting. J. Exp. Bot. 48, 1407-1413. doi: 10.1093/jxb/48.7.1407

Haliapas, S., Yupsanis, T. A., Syros, T. D., Kofidis, G., and Economou, A. S. (2008). Petunia $\mathrm{x}$ hybrida during transition to flowering as affected by light intensity and quality treatments. Acta Physiol. Plant 30, 807-815. doi: $10.1007 / \mathrm{s} 11738-008-0185-\mathrm{z}$

Hanba, Y. T., Kogami, H., and Terashima, I. (2002). The effect of growth irradiance on leaf anatomy and photosynthesis in Acer species differing in light demand. Plant Cell Environ. 25, 1021-1030. doi: 10.1046/j.1365-3040.2002. 00881.x

Hoffmann, A. M., Noga, G., and Hunsche, M. (2015). High blue light improves acclimation and photosynthetic recovery of pepper plants exposed to UV stress. Environ. Exp. Bot. 109, 254-263. doi: 10.1016/j.envexpbot.2014.06.017

Hogewoning, S. W., Douwstra, P., Trouwborst, G., Van Ieperen, W., and Harbinson, J. (2010). An artificial solar spectrum substantially alters plant development compared with usual climate room irradiance spectra. J. Exp. Bot. 61, 1267-1276. doi: 10.1093/jxb/erq005

Huché-Thélier, L., Crespel, L., Gourrierec, J., Le, M., P., Sakr, S., and Leduc, N. (2016). Light signaling and plant responses to blue and UV radiationsPerspectives for applications in horticulture. Environ. Exp. Bot. 121, 22-38. doi: 10.1016/j.envexpbot.2015.06.009

Johkan, M., Shoji, K., Goto, F., Hahida, S., and Yoshihara, T. (2012). Effect of green light wavelength and intensity on photomorphogenesis and photosynthesis in Lactuca sativa. Environ. Exp. Bot. 75, 128-133. doi: 10.1016/j.envexpbot.2011.08.010

Kamiya, A., Ikegami, I., and Hase, E. (1983). Effects of light on chlorophyll formation in cultured tobacco cells, I. I. blue light effect on 5aminolevulinic acid formation. Plant Cell Physiol. 24, 799-809. doi: 10.1093/oxfordjournals.pcp.a076580

Kim, S. J., Hahn, E. J., Heo, J. W., and Paek, K. Y. (2004). Effects of LEDs on net photosynthetic rate, growth and leaf stomata of chrysanthemum plantlets in vitro. Sci. Hortic. 101, 143-151. doi: 10.1016/j.scienta.2003. 10.003

Kubinova, L. (1994). Recent stereological methods for measuring leaf anatomical characteristics - estimation of the number and sizes of stomata and mesophyllcells. J. Exp. Bot. 45, 119-127. doi: 10.1093/jxb/45.1.119

Lee, S. H., Tewari, R. K., Hahn, E. J., and Paek, K. Y. (2007). Photon flux density and light quality induce changes in growth, stomatal development, photosynthesis and transpiration of Withania Somnifera (L.) Dunal. plantlets. Plant Cell. Tissue Organ Cult. 90, 141-151. doi: 10.1007/s11240-006-9191-2

Lichtenthaler, H. K., and Buschmann, C. (2001). "Chlorophylls and Carotenoids: Measurement and Characterization by UV-VIS Spectroscopy," in Current Protocols in Food Analytical Chemistry (New York, NY: John Wiley \& Sons, Inc.) F4.3.1-F4.3.8

Lin, M. J., and Hsu, B. D. (2004). Photosynthetic plasticity of Phalaenopsis in response to different light environments. J. Plant Physiol. 161, 1259-1268. doi: 10.1016/j.jplph.2004.05.009

Liscum, E., Hodgson, D. W., and Campbell, T. J. (2003). Update on blue light signaling blue light signaling through the cryptochromes and phototropins. so that's what the blues is all about. Society 133, 1429-1436. doi: 10.1104/pp.103.030601

McCree, K. J. (1971). The action spectrum, absorptance and quantum yield of photosynthesis in crop plants. Agric. Meteorol. 9, 191-216. doi: 10.1016/0002-1571(71)90022-7 
Mott, K., Mott, K., Michaelson, O., and Michaelson, O. (1991). Amphistomy as an Adaptation to High Light Intensity in Ambrosia Cordifolia (Compositae). Am. J. Bot. 78, 76-79. doi: 10.2307/2445230

Nardini, A., Salleo, S., and Raimondo, F. (2003). Changes in leaf hydraulic conductance correlate with leaf vein embolism in Cercis siliquastrum L. Trees Struct. Funct. 17, 529-534. doi: 10.1007/s00468-003-0265-Z

Pillitteri, L. J., and Torii, K. U. (2012). Mechanism of stomatal development. Annu. Rev. Plant Biol. 63, 12.1-12.4. doi: 10.1146/annurev-arplant-042811-105451

Prado, K., and Maurel, C. (2013). Regulation of leaf hydraulics: from molecular to whole plant levels. Front. Plant Sci. 4:255. doi: 10.3389/fpls.2013.00255

Sack, L., and Frole, K. (2006). Leaf structural diversity is related to hydraulic capacity in tropical rain forest trees. Ecology 87, 483-491. doi: 10.1890/05-0710

Sack, L., and Holbrook, N. M. (2006). Leaf Hydraulics. Annu. Rev. Plant Biol. 57, 361-381. doi: 10.1146/annurev.arplant.56.032604.144141

Sack, L., Melcher, P. J., Zwieniecki, M. A., and Holbrook, N. M. (2002). The hydraulic conductance of the angiosperm leaf lamina: a comparison of three measurement methods. J. Exp. Bot. 53, 2177-2184. doi: 10.1093/jxb/erf069

Sack, L., Streeter, C. M., and Holbrook, N. M. (2004). Hydraulic analysis of water flow through leaves of Sugar Maple and Red Oak. Plant Physiol. 134, 1824-1833. doi: 10.1104/pp.103.031203

Sæbø, A., Krekling, T., and Appelgren, M. (1995). Light quality affects photosynthesis and leaf anatomy of birch plantlets in vitro. Plant Cell. Tissue Organ Cult. 41, 177-185. doi: 10.1007/BF00051588

Sager, J. C., Smith, W. O., Edwards, J. L., and Cyr, K. L. (1988). Photosynthetic efficiency and phytochrome photoequilibria determination using spectral data. Trans. ASAE 31, 1882-1889. doi: 10.13031/2013.30952

Savvides, A., Fanourakis, D., and Van Ieperen, W. (2012). Co-ordination of hydraulic and stomatal conductances across light qualities in cucumber leaves. J. Exp. Bot. 63, 1135-1143. doi: 10.1093/jxb/err348

Schuerger, A. C., Brown, C. S., and Stryjewski, E. C. (1997). Anatomical features of pepper plants (Capsicum annuum L.) Grown under red light-emitting diodes supplemented with blue or far-red light. Ann. Bot. 79, 273-282. doi: 10.1006/anbo.1996.0341

Sharkey, T. D., and Raschke, K. (1981). Effect of light quality on stomatal opening in leaves of Xanthium strumarium L. Plant Physiol. 68, 1170-1174. doi: $10.1104 /$ pp.68.5.1170

Shengxin, C., Chunxia, L., Xuyang, Y., Song, C., Xuelei, J., Xiaoying, L., et al. (2016). Morphological, photosynthetic, and physiological responses of rapeseed leaf to different combinations of red and blue lights at the rosette stage. Front. Plant Sci. 7:1144. doi: 10.3389/fpls.2016.01144

Shimazaki, K., Doi, M., Assmann, S. M., and Kinoshita, T. (2007). Light regulation of stomatal movement. Annu. Rev. Plant Biol. 58, 219-247. doi: 10.1146/annurev.arplant.57.032905.105434

Sood, S., Gupta, V., and Tripathy, B. C. (2005). Photoregulation of the greening process of wheat seedlings grown in red light. Plant Mol. Biol. 59, 269-287. doi: 10.1007/s11103-005-8880-2

Sun, J., Nishio, J. N., and Vogelmann, T. C. (1998). Green light drives $\mathrm{CO}_{2}$ fixation deep within leaves. Plant Cell Physiol. 39, 1020-1026. doi: 10.1093/oxfordjournals.pcp.a029298

Takemiya, A., Inoue, S., and Doi, M. (2005). Phototropins promote plant growth in response to blue light in low light environments. Plant Cell 17, 1120-1127. doi: $10.1105 /$ tpc. 104.030049
Talbott, L. D. (2002). Phytochrome and blue light-mediated stomatal opening in the orchid, paphiopedilum. Plant Cell Physiol. 43, 639-646. doi: $10.1093 / \mathrm{pcp} / \mathrm{pcf0} 75$

Tallman, G., and Zeiger, E. (1988). Light quality and osmoregulation in vicia guard cells : evidence for involvement of three metabolic pathways. Plant Physiol. 88, 887-895. doi: 10.1104/pp.88.3.887

Tennessen, D. J., Singsaas, E. L., and Sharkey, T. D. (1994). Light-emitting diodes as a light source for photosynthesis research. Photosynth. Res. 39, 85-92. doi: $10.1007 / \mathrm{BF} 00027146$

Terashima, I., Fujita, T., Inoue, T., Chow, W. S., and Oguchi, R. (2009). Green light drives leaf photosynthesis more efficiently than red light in strong white light: revisiting the enigmatic question of why leaves are green. Plant Cell Physiol. 50, 684-697. doi: 10.1093/pcp/pcp034

Terashima, I., and Saeki, T. (1983). Light environment within a leaf, i. optical properties of paradermal sections of camellia leaves with special reference to differences in the optical properties of palisade and spongy tissues. Plant Cell Physiol. 24, 1493-1501. doi: 10.1093/oxfordjournals.pcp. a076672

Trouwborst, G., Hogewoning, S. W., van Kooten, O., Harbinson, J., and van Ieperen, W. (2016). Plasticity of photosynthesis after the "red light syndrome" in cucumber. Environ. Exp. Bot. 121, 75-82. doi: 10.1016/j.envexpbot.2015.05.002

Tyree, M. T., Nardini, A., Salleo, S., Sack, L., and El Omari, B. (2005). The dependence of leaf hydraulic conductance on irradiance during HPFM measurements: any role for stomatal response? J. Exp. Bot. 56, 737-744. doi: 10.1093/jxb/eri045

Voicu, M. C., Zwiazek, J. J., and Tyree, M. T. (2008). Light response of hydraulic conductance in bur oak (Quercus macrocarpa) leaves. Tree Physiol. 28, 1007-1015. doi: 10.1093/treephys/28.7.1007

Wang, H., Gu, M., Cui, J., Shi, K., Zhou, Y., and Yu, J. (2009). Effects of light quality on $\mathrm{CO}_{2}$ assimilation, chlorophyll-fluorescence quenching, expression of Calvin cycle genes and carbohydrate accumulation in Cucumis sativus. J. Photochem. Photobiol. B Biol. 96, 30-37. doi: 10.1016/j.jphotobiol.2009.03.010

Wang, W. J., Sun, X. T., Wang, G. C., Xu, P., Wang, X. Y., Lin, Z. L., et al. (2010). Effect of blue light on indoor seedling culture of Saccharina japonica (Phaeophyta). J. Appl. Phycol. 22, 737-744. doi: 10.1007/s10811-0109514-X

Xiong, D., Yu, T., Zhang, T., Li, Y., Peng, S., and Huang, J. (2015). Leaf hydraulic conductance is coordinated with leaf morpho-anatomical traits and nitrogen status in the genus Oryza. J. Exp. Bot. 66, 741-748. doi: 10.1093/jxb/ eru434

Conflict of Interest Statement: The authors declare that the research was conducted in the absence of any commercial or financial relationships that could be construed as a potential conflict of interest.

Copyright (c) 2017 Zheng and Van Labeke. This is an open-access article distributed under the terms of the Creative Commons Attribution License (CC BY). The use, distribution or reproduction in other forums is permitted, provided the original author(s) or licensor are credited and that the original publication in this journal is cited, in accordance with accepted academic practice. No use, distribution or reproduction is permitted which does not comply with these terms. 